\title{
The Level of Factors Influences on Customer's Adoption of Internet Banking: The Case of Vietnam
}

\author{
Do Hoai Linh", *, Nguyen Phuong Linh ${ }^{2}$ \\ ${ }^{1}$ Banking Department, School of Banking and Finance, National Economics University, Hanoi, Vietnam \\ ${ }^{2}$ International School of Management and Economics, National Economics University, Hanoi, Vietnam \\ Email address: \\ linhdo.neu@gmail.com (Do H. Linh) \\ *Corresponding author
}

To cite this article:

Do Hoai Linh, Nguyen Phuong Linh. The Level of Factors Influences on Customer's Adoption of Internet Banking: The Case of Vietnam. International Journal of Economics, Finance and Management Sciences. Vol. 5, No. 3, 2017, pp. 194-203.

doi: 10.11648/j.ijefm.20170503.19

Received: April 29, 2017; Accepted: May 10, 2017; Published: June 23, 2017

\begin{abstract}
This article aims at assessing the level of factors influencing on customer's adoption of Internet banking (IB) with the case of Vietnam. The study took primary data from in-depth interview and sample of 536 respondents surveyed from December 2016 to March 2017. Knowledge and Income, Trust and Risks, Banks and Government are factors affecting on customer's adoption of IB in Vietnam. Based on findings, recommendations to banking sector and the Government are introduced, in which the adoption of using IB in Vietnam may improve.
\end{abstract}

Keywords: Internet Banking, Adoption of Customer, Vietnam

\section{Introduction}

The beginning of digital innovation from industrial revolution 4.0 that lead to the completely expectation of human life. Industry 4.0, said by Klaus Schawab [1], which used technological information and electronics to enhance the productivity, includes cyber-physical system combining with the Internet. It is transforming most of the industry in every country in both production and management systems, especially in banking sector, Internet banking is a new innovation that happened in banking sector as one of the digital channel to promote and stimulus the mass customer at real time demands. Internet banking users in Vietnam increased $57.1 \%$ in the last quarter of 2016, comparison with six years ago though $22 \%$ population using online banking. With a goal of getting evolution of e-banking, banking industry set up strategies to attract their customers and find out some factors impact on consumer's behaviors based on the background of them as Park and Jun, Koufaris [2, 3] said. On the other hands, the limitations in developing economy and technology will border the activities and bring about risks in adopting internet banking claimed by Reza Shafei and Vala Mirani [4]. For these reasons, this study aims to empirically investigate the key components which affect the acceptance of online banking among developing countries, particularly in Vietnam.

\section{Literature Review}

\subsection{Internet Banking}

Internet banking is known as the automated mean of new banking creation and services to users via technological system that enable financial institution individuals or firms to access account or information by Internet said by Petrazzini [5]. Among the commonly used IB services involved managing balance, funding or purchasing bills.

\subsection{Banking System in Vietnam}

Vietnam, located in Southeast Asian, is maintaining efforts to liberalize the national economy and implementing reform policies as well as creating necessary infrastructures to innovate in the economic situation and make more competitive export industries. Internet banking invested by World Bank (WB) has started operations since May 2002. This activity gave an impulse to change and modernize banking system of country. The popularization of internet 
and smart phone recently creates more potential opportunities for Internet banking services. According to General Statistics Office of Vietnam (GSO), until December 2016, more than 52 million people use Internet. This was expected as a potential opportunity to develop E-Banking services in Vietnam; hence, Vietnamese government issued Decree No. 2545, set up goals in period 2016-2020 issued by State Bank of Vietnam (SBV) [6] as following: (1) To end of 2020, the total cash in circulation is below $10 \%$; (2) $70 \%$ of electricity, water, telecommunications and communications service providers accept bill payments of individuals and households through non-cash payment; (3) $50 \%$ of individuals and households in big cities use non-cash payment as means for purchasing; (4) To focus on increase a number of new and modern payment facilities and services for rural, remote and isolated areas, contributing to promote financial inclusion

Although IB in Vietnam has just been introduced into public since 2002, Vietnamese mostly keep their trades and transactions in cash. The market for developing IB in Vietnam is still large.

\subsection{Factors Impact on Users'Adoption of Internet Banking}

\subsubsection{Banks'Strategies and Internet Network}

Jayawardhena and Foley [7], Gerrard and Cuunningham [8], Wai-ching Poon [9] found that strategies and how they worked are factors of electronic banking to the customer's adoption. The attractive designs, eye-catching colors or heading and the propensity to show good-looking of bank's representation were the impulse-elements which pushed up the percentage using IB from customers. On the other hand, the content of products and services of IB that introduced on the website plays an important role in effecting this kind of banking acceptance. Still be Gerrad and Cunningham [8] found, paramount responsibility in content of website makes much easy to approach users; an addition of loan calculators or converted exchange rates would draw the notice of people who visit the bank's website. Not only users, but non-users also mind about the change in interest rate or benefit of savings. One noticeable thing is a significant relationship between download speed and customer's pleasure, said by Hoffman and Novak [10]. This speed mostly relies on the stable network, the size of content, hard-ware and soft-ware of the computers; Jayawardhena and Foley [7] believed that the connected method to download also involved. As said by them, almost bank's websites will attach the content files or snapshots which require customers to run some supplemental programs to view those files. Jun and Cai [11] considered the visitors would be dissatisfaction because of expected viruses and hard disk size when they download extra program; leading to slowdown the computer's speed and lowering expectations from user. Furthermore, customer's decision on using Internet banking services partly depends on fees and charges, according to Wai-ching Poon [9].

\subsubsection{Perceived Benefits}

According to Lockett and Litter [12], research in the UK showed the model to prove the awareness of benefits from both adopters and non-adopters got from IB was available 24 hours per day, while the faults and risks were two negative objects. Similarity to Sohail's research [13], knowledge of electronic banking and its advantages are the most important outcome impacts on perceived usefulness and perceived ease of use; then the speed of internet connection and social efficiency. Wai-ching Poon [9] investigated limitations of entrance to better acceptance of electronic banking and the connection between the usage of internet banking and the demographic characteristics divided by groups such as age, education, jobs and income level.

\subsubsection{Confidence and Risks}

In term of trust, most of previous researchers believed that usage of IB increase only when confidence is improved. Mukherjee and Nath [14] elicited in case of India, consumers commonly hesitate about their personal information unexpectedly leaks out to be misused by hackers, particularly for financial purpose, investigated by Aladwani [15] and Black et al. [16]. Security and privacy are two necessary elements which could ensure user's belief to adopt transaction system via Internet. Hutchinson and Warren [17] suggested the smart card with an identity fingerprints could be more secured instead of entering password.

Fedrizzi et al. [18] examined transaction risk as the sufficient elements. The fraud issues have happened in banking services system since the widespread internet developed and traditional form to virtual conditions. In case of Slovenian economy, Sokolov [19] also believed that there are three main exposures causing the untruth in customer were strategic risk, operational risk and credit exposure.

\subsubsection{Government Supporting}

Jaruwachirathanakul and Fink [20] believed all of supports from the government also enhance people's awareness on Internet banking. Their investment in high technological facilities could be seen clearly in developed economies like Japan, Singapore, according to Chong [21]. Bums [22] elicited in the period of $1990 \mathrm{~s}$, the Singaporean government was succeeded in increasing adoption rate of EDI (electronic data interchange) by education and providing success experiences from other economies. Compare to Malaysia, government used the method to endorse the internet services like creating more political and government websites that make citizen easy to access; therefore, that would be psychological foundation for customers to be confident and more trust in Internet banking.

\subsubsection{Customers}

Serkan Akinci and Safak Aksoy [23] mainly focused on attitudes and behaviors of customers, truly based on statistical data and empirical evidence to see the IB usage and development of allocation channel organization for banking services in society, claimed by Byers and Lederer [24]. Both of these two researches directly objected customer's demography was key factor; and Serkan Akinci [23] expected that consumers at higher education level were their biggest 
segment for banking institutions. Concretely, this research covered the demography and the various delivery channels of both Internet banking users and non-users in high education part. Other points gave comparison of behaviors of two groups of people and figured out the similarities between different online banking and group services in homogenous sorts.

\subsection{Research Gaps}

Almost previous works only mentioned and analyzed about the role of each implications and how it affected on customer's adoption of online banking; in this paper, both aspects of preference and perception factors of customer will be incorporated to discuss deeply.

\section{Methodology}

The study uses in-depth interview and questionnaire approaches with statistics analysis, empirical framework would be discussed. The below graphic displays briefly how the research process in conducting:

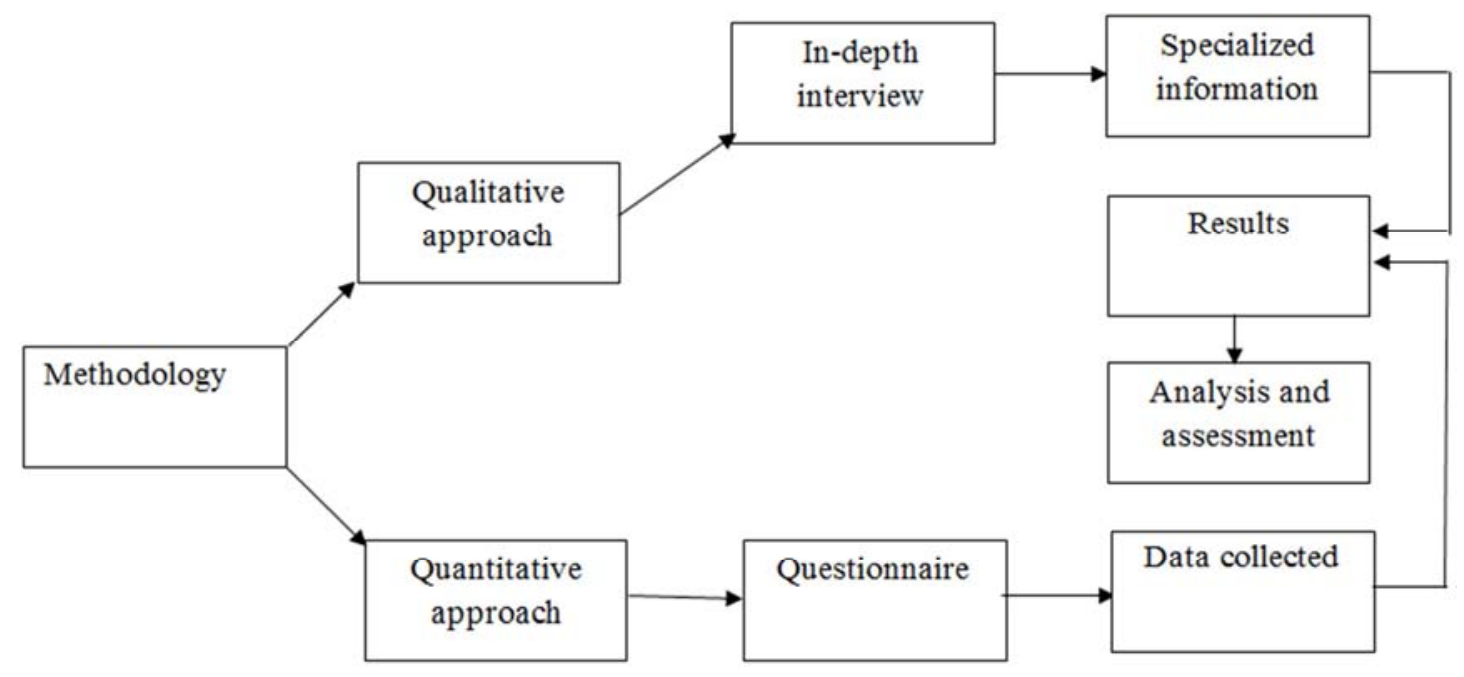

Figure 1. Research framework.

\subsection{Analytical Framework}

Based on previous works, almost authors indicated two main aspects consist of preference and perception which will be the implications impact on customer's adoption of Internet banking in developing economies, in this case is Vietnam. The structure below is strongly influenced by the previous research of Alain Yee-Loong Chong et al. [21] and WaiChing Poon [9].

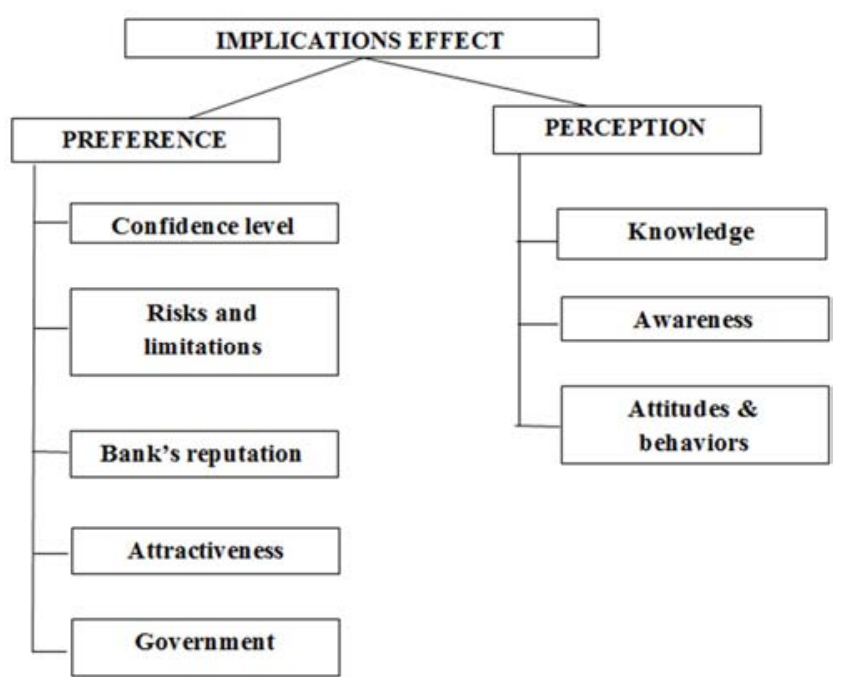

Figure 2. Framework of implications effect on IB adoption of Vietnamese customers.

\subsection{Interview and Questionnaire}

\subsubsection{Questionnaire}

Questionnaire was designed base on Likert scale from "1" the lowest point to " 5 " the highest point which aim at evaluating the levels of respondent agreement. 600 people chosen including adopters and non-adopters who are university's students, officers, households as well as bank's clients with $80 \%$ of them live in vibrant cities, they are Hanoi, Ho Chi Minh City - 02 biggest cities of Vietnam and $20 \%$ left living in others; then the collected respondents were 536 valid answers.

\subsubsection{In-depth Interview}

To assure there is no bias, face-to-face approach was also applied to collect the respondents from bank customers. A bank manager who was directly interviewed will give specific views and details about online banking in Vietnam. The questions in interview were also designed with the similar construction as questionnaire but more specific in order to assembling the variety of answers.

\section{Results and Discussion}

Generally, among 536 respondents, $80.2 \%$ of them have been using the online banking services until now, meanwhile, $19.8 \%$ of total among 536 respondents having no experience about this type of service. 
Table 1. Assessment of level impacts of factors on online banking adoption.

\begin{tabular}{|c|c|c|c|c|c|c|c|c|}
\hline \multicolumn{9}{|c|}{ Degree of agreement (\%) } \\
\hline Factor & 1 & 2 & 3 & 4 & 5 & Unrated & Mean & Std dev. \\
\hline User's knowledge & 42 & 62 & 106 & 150 & 176 & 0 & 83.33333 & 67.80757 \\
\hline Government supports & 192 & 74 & 138 & 26 & 48 & 22 & 77.33333 & 69.68118 \\
\hline The high income & 71 & 18 & 46 & 86 & 137 & 52 & 62.33333 & 37.79242 \\
\hline Confidence-level & 30 & 70 & 28 & 74 & 186 & 32 & 64 & 58.03447 \\
\hline Fees and payments & 18 & 80 & 64 & 122 & 170 & 12 & 71.66667 & 56.54615 \\
\hline
\end{tabular}

(Source: Primary data)

The following results would be analyzed and discussed relying on the classification of IB users and non-users to point out the major outcomes considerable effects users' acceptance IB in Vietnam.

\subsection{Knowledge and Education}

\subsubsection{Demographic Information of Customers}

Table 2. Typical occupations of Vietnamese respondents.

\begin{tabular}{ll}
\hline Occupation & \% \\
\hline Student & 39.7 \\
Office worker & 23.8 \\
Authority & 23.8 \\
Businessman & 7.1 \\
Freelancer & 3.2 \\
Retired person & 0.8 \\
Other & 1.6 \\
\hline
\end{tabular}

Based on the survey collected, the age between 19-25 occupied more than half of the answers with $54.6 \%$ that elicited themselves as the primary users of the network because the nature of survey was conducted online, which partly explained the role of these potential customers for IB in Vietnam. Meanwhile that, the pattern indicated the next Internet users belonged to aged group in proportion of 26-33 (23.8 percent) and mid-age $34-52$ (19.2 percent). There is a noteworthy that the respondents at a group 53-71 are Internet users but the percentage considerably small at only 1.5 percent. With $0.8 \%$ compared to others, being roughly to very few people, the oldest age group less likely to use the network. Age-ranges divided based on the demographic cohort like Generation X, Y or Z. Young generation has propensity of being familiar with modern technology, apprehending quickly compare to old group.

Additionally, the Table 2 shows the occupational classification of answers to see percentage of intellectuals responding to IB questionnaire. The student rate is $39.7 \%$ corresponding with the highest rate of total occupations. The office worker and authority, basically originating from high education level, has a parallel rate at $23.8 \%$. People run their business occupied $7.1 \%$ and self-employers with unstable work have $3.2 \%$. There are only one or two retired respondents representing to group of modern technologically limited as old people. Other left has different jobs at $1.6 \%$ rates however it does not affect much as other popular occupations. In specific, student as the group of people have enough knowledge and certain education level meet early the modern technology as well as more connecting network opportunities, distribute their role in IB diffusion in Vietnam. Follow the Vietnamese resolution No. 2545 [6] promulgated on December $30^{\text {th }}, 2016$ about using online banking instead of cash in period 2016 to 2020 , in order to stimulus IB using demand and amount of IB customers, raising the rate of people aged 15 and over has owned banking accounts, attain at least $70 \%$ in 2020.

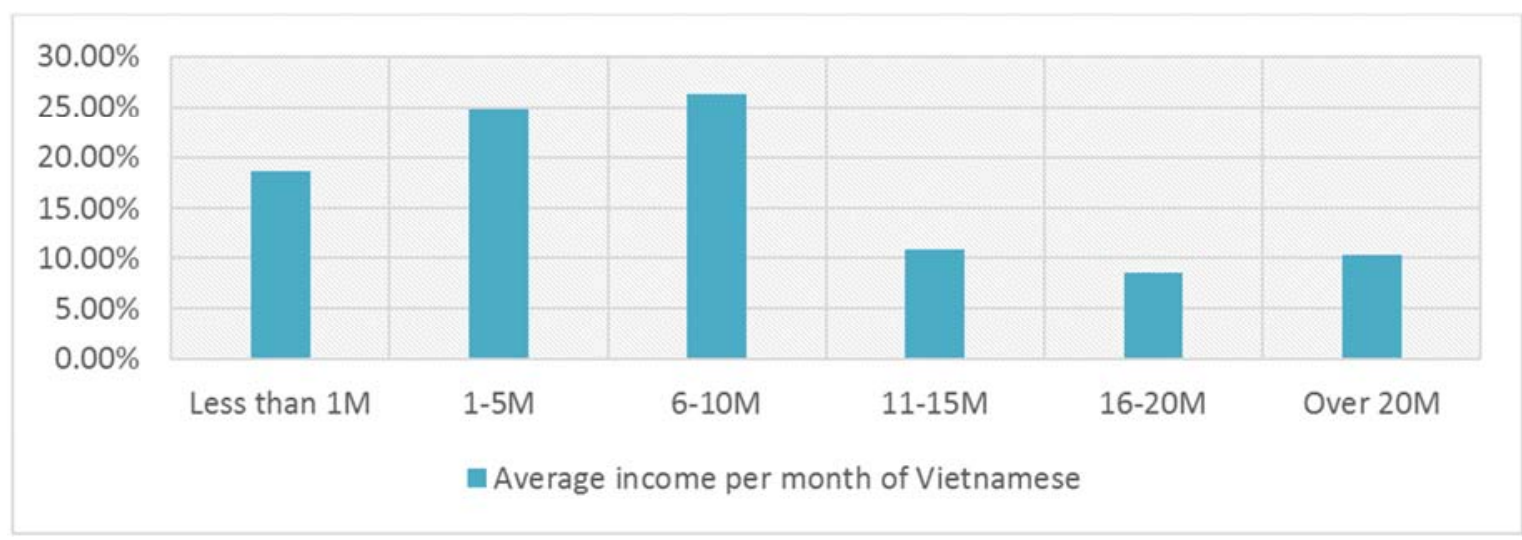

(Source: Primary data)

Figure 3. The percentage of income level per month in Vietnam (VND).

The results illustrated in Figure 3 indicates the average wage in one month of one Vietnamese in VND with uneven the distribution of wages and mainly concentrates in the first three income level. In 2016, a signal of significant economic growth of Vietnam reflects an increase in national GDP by $6.21 \%$, in comparison to last year [25]. 
On the other words, stable wage and be propensity toward higher are results of economic growth in area; promotes supply and demand in economy. When the necessary and sufficient conditions meet the demand, freely customer's spending tends to raise up. It does not mention the IB services likely requires its users own smart phone or home PC to access Internet, said by Wilson [26] and consumers need devices with the latest technological; thus household income at upper and middle level had a significant impact on customers' acceptance of Internet banking, which is consistent with outcome of Mattila et al. [27] and Wilhelm [28].

\subsubsection{Premise of Knowledge Factor}

The survey result in Figure 4 presents how customers mind about the benefits they can get when being IB users, connecting to customer's profile like income level, occupation, age. The graph shows the high rate of the best benefit selections; proving customer's perceived usefulness. Concretely, transferring money in everywhere at any time is one of the prominent benefits of IB; almost respondents (only IB adopters) are fully aware of it when the percentage reaches $91.6 \%$. Next two core functions of IB are saving user's time and easy to individually control and manage bank account with $83.2 \%$ and $76.6 \%$ respectively. By that way, this research also elicits each person aware which advantages they can get more than the traditional bank and how efficiency this service brings about. These findings are consisted with the previous researches of Rao et al. [29], Pikkarainen et al. [30] and Gounaris and Koritos [31].

\section{CUSTOMER'S AWARENESS BENEFITS OF E-BANKING}

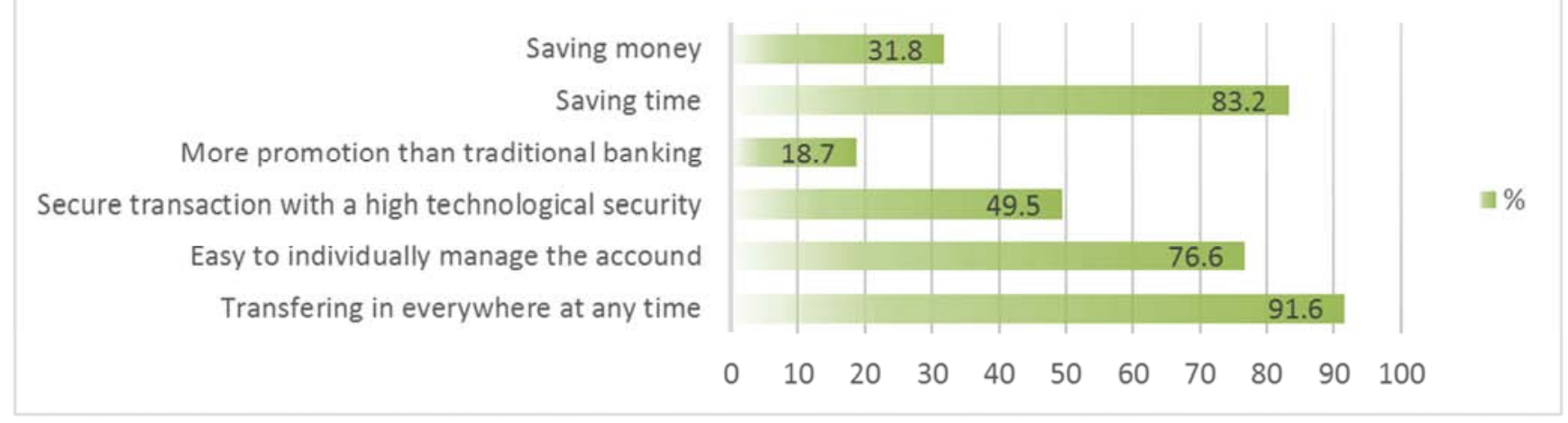

(Source: Primary data)

Figure 4. Percentage of perceived benefits of IB from customers in Vietnam (\%).

Quote from the answers of one of interviewee considered that:

"Standard of customers can also be one of factors effects on customer's adoption of online banking. The older generations, especially people live in the countryside, is Internet contact limited. When there is no experience and gathering the basic knowledge as well about Internet or unaware of operating system like Android, IOS, Windows, those people have a vague estimate and experience of usefulness of IB services; then comes hard to approach".

The uneven education distributed among different cities is a big issue which Vietnamese authorities are facing currently; the reason comes from the gap between rich and poor households in Vietnam. The rich-poor gap tends to increase and according to the latest published data of the WB and the GSO show that the difference coefficient has increased steadily from 8.1 (2002) to 9.4 (2012). The poverty rate in ethnic minority areas is still high and occupies nearly $50 \%$ of poor people in the country. Although the Vietnamese Government has issued many policies to encourage learning and financial support for this group every year, they cannot afford the comprehensive education system; thus approachable technology possibility of this group is low or impossible. In this case, the diffusion or adoption of online banking meets an obstacle if customers are unknowledgeable.
That interviewee also gave supplementary idea:

"Later generations from the 1980s to the present (known as Generation $Y$ and over) includes people who are better educated with better knowledge of telecommunications and information technology. Along with a good infrastructure, the trend of access to E-Banking of people is almost inevitable. Moreover, at a certain level, they will aware of better security for electronic transactions. One simple thing to prove is that E-Banking is mainly implemented in big cities but has not developed in rural areas and countryside yet".

This interviewee emphasized that in major economic areas, facilities and education system are invested, expanded and developed faster than undeveloped areas, especially Vietnam is a developing country, such underdeveloped areas account for nearly two-thirds of the country so the shortcomings in education distributed rather limits the diffusion of IB over the country.

In overall, these theoretical evidences explained for the customer attitudes and buying behaviors in IB adoption; as a result, by the demographic background, meaningful outcome can be point out. With the findings of Wai-ching Poon [9], Harrison and Rainer [32], different in age groups, knowledge and education level, wages decide consumer's attitudes making foundation to increase IB acceptances among customers in Vietnam. 


\subsection{Confidence Level and Risks}

\subsubsection{Confidence Level/Trust}

Another critical factor impacts on adoption IB is confidence level or called 'trust'. This is regarded as one of the most important factors having the significant impacts on the mindset, behavior as well as the acceptance of online banking from both adopters and non-adopters, though educated and uneducated customers in Vietnam.

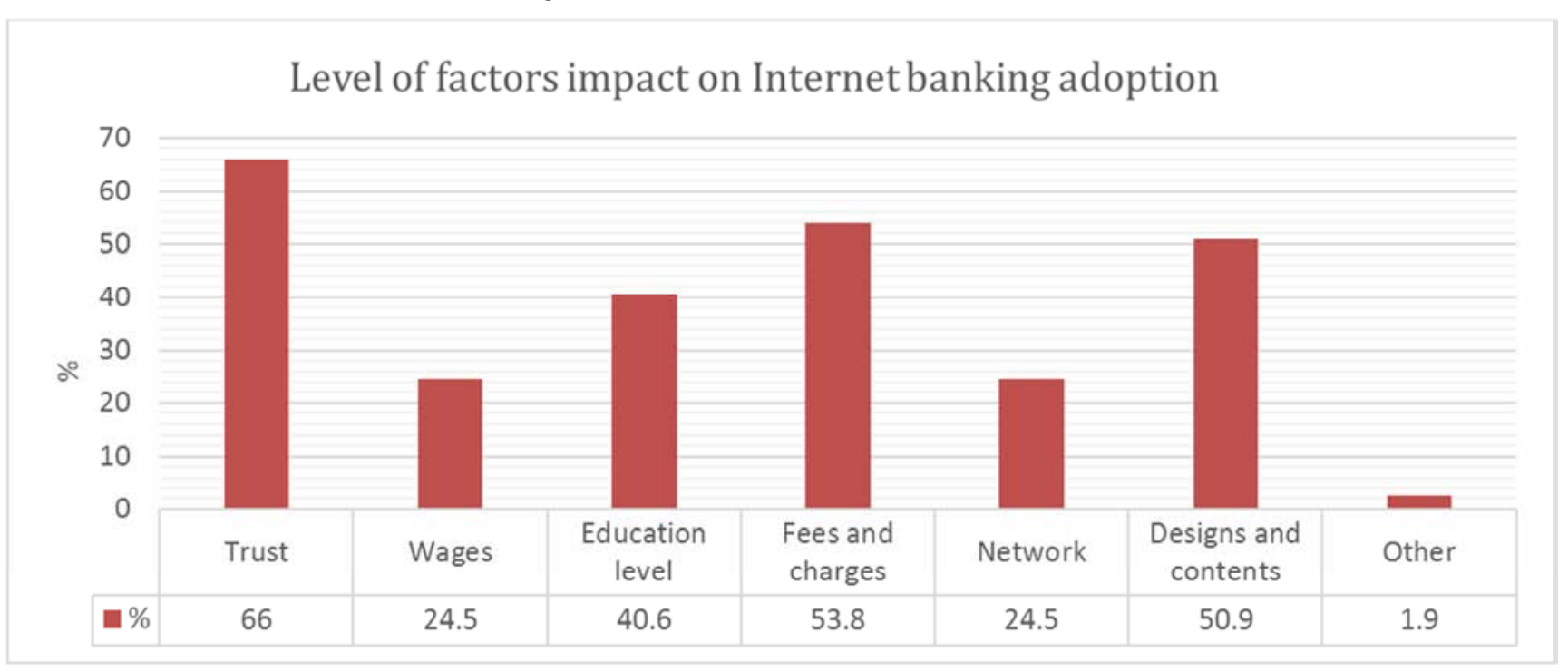

(Source: Primary data)

Figure 5. Level of core factors effects on customer's adoption of IB in Vietnam (\%).

It can be seen clearly in Figure 5 above that psychological impact of customers makes their decision of whether to be electronic banking clients or not. 66 percent of total believed customer's faith in IB would be shaken if none of security or privacy was not guaranteed by banking sector, leading to the elimination of online banking. This index is higher than other factors in comparison with overall. Although only a few cases of customer's information and deposit stolen in Vietnam (the case of Huong, H.T.N [33] who lost 500 million VND at VCB), it has affected a lot on consumers' psychology of network security. When the customer's confidence lowers their loyalty in online banking, the acceptance of this service is significantly under the influence, which is consistent with results of McMahon and Friedman et al. [34, 35]

Besides, users especially from developing economies used to transfer money face to face; means they prefer the traditional banking than electronic banking because a fear of personal information leaked out for illegally finance purposes, which was revealed by Black et al [16]. The interviewee expressed an idea:

"Habits of using cash with the fear of the electronic transaction security are barriers to slow down accessibility and IB growth-speed, especially after a series of security incidents occur to the bank in Vietnam recently"

Table 3. Frequency of using online banking (\%).

\begin{tabular}{ll}
\hline Daily & 19.5 \\
Weekly & 33.6 \\
Monthly & 34.6 \\
Quarterly & 12.3 \\
Yearly & 0 \\
\hline
\end{tabular}

(Source: Primary data)
Simultaneously, the Table 3 presents that there are $34.6 \%$ of respondents using IB services monthly, $33.6 \%$ of the respondents using weekly, $19.5 \%$ of respondents using daily, $12.3 \%$ of respondents using quarterly and there are no one using yearly. This index reflects online banking is not really widespread and not yet popular for use as a regular remittance tool.

\subsubsection{Risks and Limitations}

There are particular risks attached when a security incident happens. Risks come from many reasons as an inevitable consequence of other factors such as lack of knowledge.

Table 4. Percentage of problems arising when customers use online banking services (\%).

\begin{tabular}{ll}
\hline Internet problems & 68.3 \\
Security flaw in system & 16.3 \\
Mistakes come from banks & 15.4 \\
Complex system & 12.5 \\
Other reasons & 8.7 \\
\hline
\end{tabular}

(Source: Primary data)

The Table 4 illustrates some outstanding issues arise during customer's using process, according to survey results. These problems include strategic risks, reputational risks and operational risks but mostly are operational risk which associated with legal risk, transaction risk, security risk or IT risk, be also revealed Jayaram Kondabagil [36]. Almost Vietnamese are facing with the internet problems. Up to $68 \%$ respondent complained about the low network or the interruption during the transfer process. It effects on ability to deliver money, in case it causes substantial fraud losses 
containing the privacy and integrity of user data because of tampering information. There are $16.3 \%$ of respondents met security flaw in system, not so usually occur in IB system but once it happens, clients will suffer damages of financial losses as the worst undesired consequences, as the following instance.

Risks generally arise from the limited knowledge of clients, superficial thought and acting carelessly leading them easy to be taken into the trap scammers by sophisticated tricks taking technological advantages. Scammers mainly focus on the elder customers, who do not use technology as proficient as younger group. The mistake come from banks and complex IB system are in proportion $15.4 \%$ and $12.5 \%$ which will be discussed in Section 4.3 to find out how it impacts on customer's approval if these factors is passed on to consumers.

\subsection{Supports from Banking Sectors and Vietnamese Government}

\subsubsection{Banking Sectors}

Figure 6 shows knowledge about IB including how to use, risks, policies and term of customers. The rate of people confident approximately paralleled that of unconfident respondents with $42 \%$ and $40 \%$ respectively, $14 \%$ of respondents totally confident and $4 \%$ of respondents almost know nothing about terms or policies as well as risks. The index shows their lack of learning about IB terms relative. Partly due to carelessness from users before using, which can cause some unexpected risks, other comes from management decision of banks. Banks need to provide more detail and spread out the policies and the instruction for use for users, especially elder objects due to their technological misunderstanding and also make clear and friendly to users. Moreover, the growing number of cyber-criminals and scams made users feel insecure and lost faith; hence, banks came up with solutions, tighten policies and strictly security as well as supplement tough regulations for punishment.

Looking back the Figure 5, 50.9\% of respondents believed that they were attracted by the eye-catching colors, reasonable structure and good design for the home page of IB. Bank should exploit every condition, possible IT means to perform well their IB widespread to both adopter and nonadopter. By that way, users have propensity of being attracted by the financial information, saving interest rate or client's benefits and promotions right on the heading of the bank's website. They can feel free to register immediately if bank satisfy them in aesthetically aspect, same as Gerrad and Cunningham [8]. One noticeable thing that, $53.8 \%$ of respondents considered the fees and charges made customer's hesitative choice. They attentively care to fees of transaction costs of IB services, commonly prefer at lower level or acceptable prices (Figure 5). This fees significant impact on adoption positively or negatively depend on the its going up or down because if banks serve the unreasonable online transaction cost, in comparison with traditional ways, it will obviously discourage IB's acceptance to maintain the traditional approaches and this conclusion consisted with finding of Sathye [37].

\section{CUSTOMER'S CONFIDENCE OF RISKS, POLICIES}

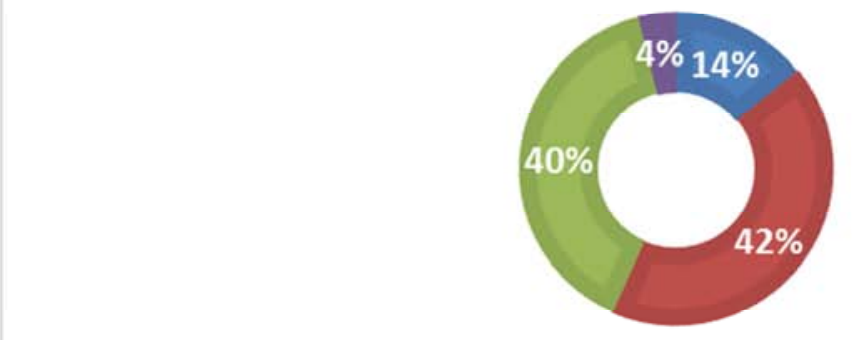

(Source: Primary data)

Figure 6. Confidence levels of customer about risks, policies (terms of IB).

\subsubsection{Government and Authorities in Actions}

Besides that, Government supports have significant impacts on acceptance of consumers, especially in developing economy like Vietnam. The Figure 7 below presents the number of respondents considering level of reaction of their government in boosting up online banking services in Vietnam. The clients almost rated for the government's action at "1" correspond to the Lowest point or Strongly disagreement; means at present, the interaction between the government and impulse IB services in Vietnam is still at low rate. Clients do not realize the step in of authorities in supporting widespread benefits of online banking. The number of respondents agree with the actions of the government is not many in comparison with the disagreement; therefore, the government should have severely methods to improve this atmosphere among clients. 


\section{ASSESSMENT OF IB USER TO REACTION OF THE VIETNAMESE GOVERNMENT}

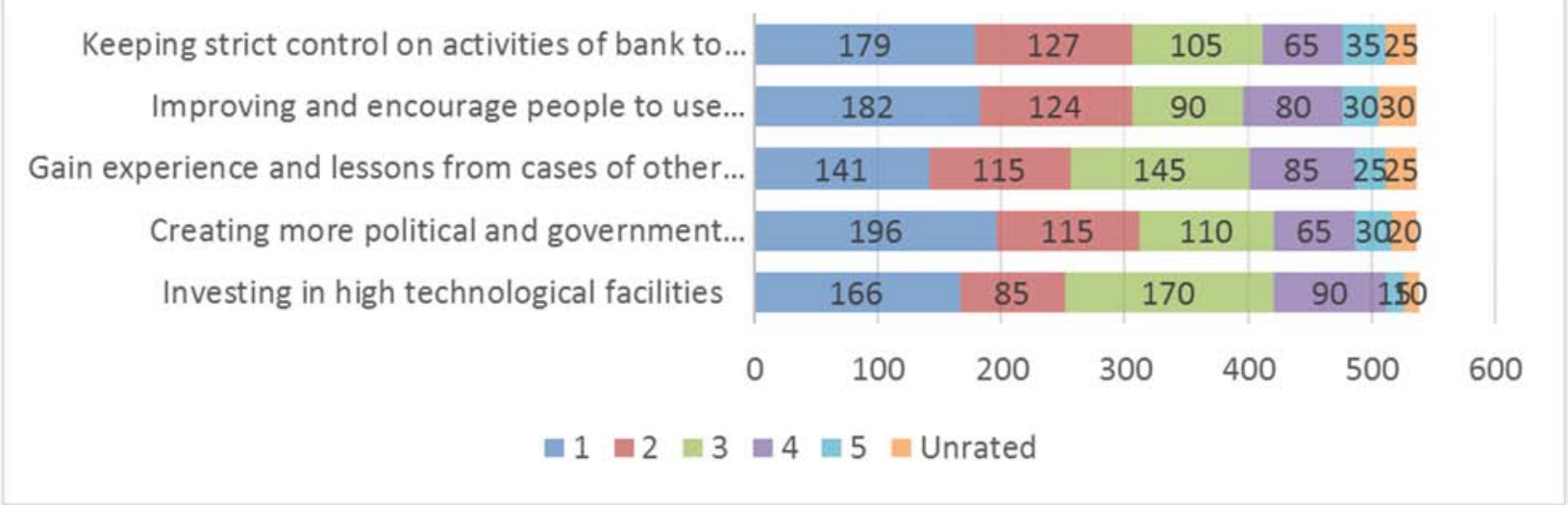

(Source: Primary data)

Figure 7. The assessment of IB user to reaction of the Vietnamese government in pushing up services in country recently.

\subsection{Summary}

Based on the discussion above, the research summarizes main results divided into three groups of factors: Knowledge and Income, Confidence level/trust and Risks, Banks and the Government; then presents in the following figure:

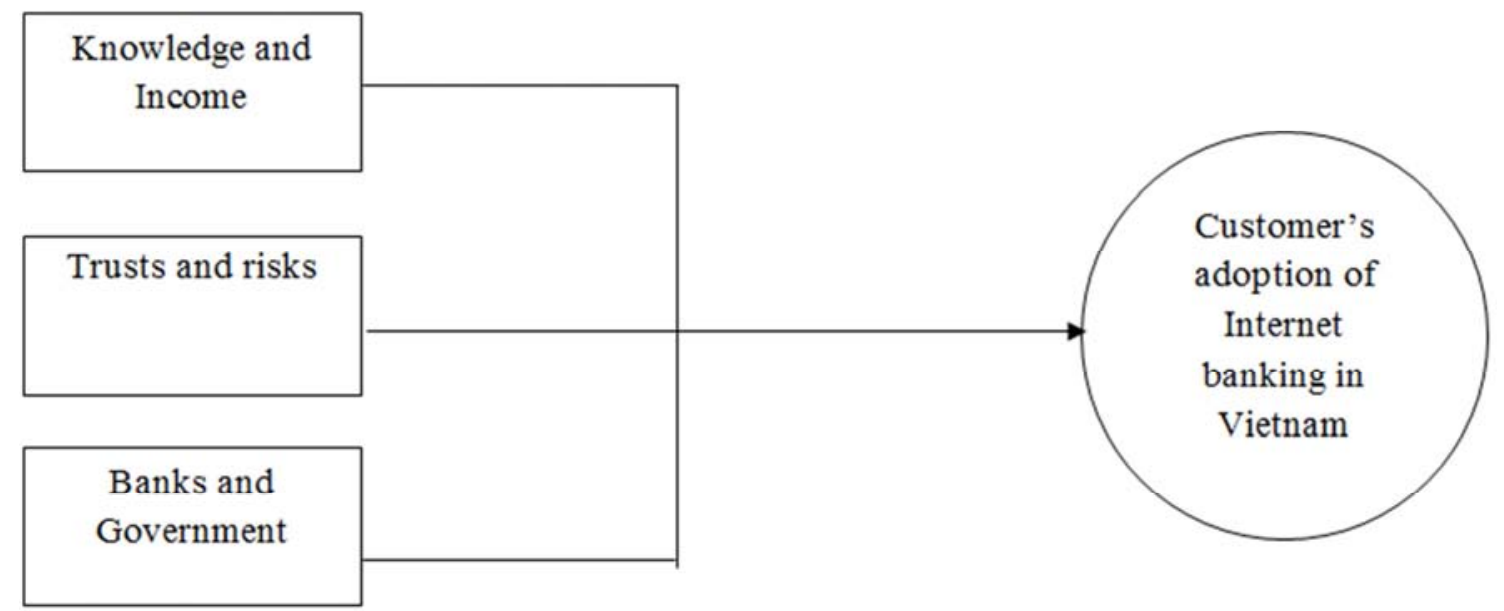

Figure 8. A summary implication of online banking in Vietnam.

\section{Recommendations and Limitations}

Based on the findings, both of banking sector and the Government should eliminate those risks, disadvantages and stimulus the using demands from user and gain the achievements.

\subsection{Recommendations to Banking Sector}

According to the analysis above, banks need to catch the customer's psychology, raise vigilance and make trust from them by setting the appropriate regulations and giving strictly punishments to control on activities of banks to avoid risks exposure. Because of recognizing the growing trend of cyber-crime in technological era, banks rather regularly posted information on the official website with the warning content of fraudulent transactions, instructing customers to safely use online banking services. Banks need also directly inform customers through the SMS system and email which customers have registered, as well as spread out information on media.

For each time of warning to clients, banks should pay particular attention to the common fraud tactics, the notes when using the service and recommend users only log in IB services on the banks' officially website. Customers are advised to regularly monitor private information and comply with safety transaction instructions. Simultaneously, banks affirm that its system is safe, secure to raise reputations and confidence level from clients, committed to maximum efforts 
in restricting and preventing fraud in order to protect the legitimate customer's interests. This will assure bank's reputation has more efficiency and also raise the competitiveness between Vietnamese banks.

Nevertheless, banks should introduce the promotion for IB adopters such as low fees or charges, higher saving interest rates; it not only remains the quantity users but also attracts non-users. According to Vietnamese resolution No. 2545 [6], managers stipulate the certain fee for transfer, payment and withdrawal of cash at branches of foreign banks by increasing the cash transaction fee and reducing the non-cash transaction fee; reducing of fees for inter-bank payment transactions and ensuring reasonable fee rate, creating a fair market competition, avoiding monopoly among banks. When customers realize the potential advantages from being IB user more than traditional way, they definitely move to use online way instead of face-to-face transaction.

Another way to improve IB services is, customer services department should regularly listen to suggestions and recommendations from their customers about the quality services; thus bank will know what the customer is facing with and fix it in time to prevent cyber-crimes from exploiting the vulnerability to steal customer information, partly enhance bank's reputations and user's psychological safety and the online banking adoption also increase.

\subsection{Recommendations to the Vietnamese Government}

During the industrial revolution 4.0, Decree No. 2545 [6] of approval of the Non-Cash Payment Development Scheme in Vietnam was promulgated for the 2016-2020 period. Concretely, before officially declare the regulations, research and decree regimes, policies to encourage purchasing by online banking in taxes, payment by E-commerce transactions. It is also acceptable for bill of regular and periodical services such as electricity, water, telephone, Internet. Both the Government and banks should encourage retailers of goods and services to accept and use electronic payment instruments and assist customers in making online payment transactions in the process of purchasing and selling goods or services. The Government should facility banks to research; apply new modern payment technologies at reasonable cost, fast payment rate, simple, convenient and high quality. In addition, the authorities need to promote the development, application of modern means of payment or remittance appropriately to countryside's conditions (payment via Internet, digital devices) in order to stimulus non-cash payment.

The network problems are the most essential factors which most of Vietnamese are facing so that the Government needs to attach special important to invest modern facilities and ensure a stable and fast network connection. Transmission troubles often cause customers to feel uncomfortable, inconvenienced or conjure up the insecure feelings about the money transaction; thus, the Government may decree many regulations or encourage people to use IB services, but they need to improve the network firstly.

Not only banks but the Vietnamese Government should also help to assure the laws related to IB. The solid and clear regulations can get more belief from users that the security system and private. Moreover, the Government can also do the same as banks in spreading out by social media to diffuse the online banking widely. Another way the Government can increase the customer's knowledge that organizes the "Safety and Internet Banking" contests to encourage clients to selfresearch about IB policies, and then limit the risks as much as possible.

\section{Conclusion and Limitations}

This primary data of the paper revealed results to discuss and analyze the level impact of implication involved in customer's adoption of online banking services in developing countries, the case of Vietnam with three groups of major objective determinants: Knowledge and Income, Trust and Risks, Banks and the Government. Summarize of all previous researches with the same or related topic was a foundation for the methodology as well as results. Finally, some recommendations were given out based on the surveys collected from desirousness of respondents to improve and cover the shortcomings of IB; in order to stimulus quantity demand of using IB from customers with expectation that they could experiences these convenient services.

There still exist some limitations during the research process. The lack of data sources to run the model regression leading to the significant of impact could not be explained clearly and solidly. Next, this current project only concentrates on a group of Vietnamese objects and has the insights into Internet banking acceptance issues in developing economies; further researches also apply the research framework to others. Finally, the research focused three groups implications included perception and preference of customers, thus it cannot cover all of other factors that may effect on the IB acceptance in Vietnam. There will be some of other factors like cultural issues, geographical issues that can be potential objects for future studies research

\section{References}

[1] Schwab, K. (2016). The fourth industrial revolution. 1st ed.

[2] Park, C. and Jun, J. K. (2003). Effects of internet usage, perceived risks, and innovativeness. International Marketing Review 20: 534-53.

[3] Koufaris, M. (2002). Applying the Technology Acceptance Model and Flow Theory to Online Consumer Behavior. Information Systems Research 13: 205-223.

[4] Shafei, R. and Mirani, V. (2011). Review Designing a model for analyzing the effect of risks on e-banking adoption by customers: A focus on developing countries. African Journal of Business Management 5: 6684-6697.

[5] Petrazzini, B. and Kibati, M. (1999). The Internet in developing countries. Communications of the ACM 42: 31-36. 
[6] Thuvienphapluat. vn. (2016). Approving the scheme for the development of non-cash payments in Vietnam during 20162020. Retrieved March 9, 2017 from https://thuvienphapluat.vn

[7] Jayawardhena, C. and Foley, P. (2000). Changes in the banking sector - the case of Internet banking in the UK. Internet Research: Electronic Networking Applications and Policy 10: 19-30.

[8] Gerrad, P and Cunningham, J. B. (2003). The diffusion of Internet banking among Singapore consumers. International Journal of Bank Marketing 21: 16-28.

[9] Poon, W. (2008). Users' adoption of e - banking services: The Malaysian perspective. Journal of Business \& Industrial Marketing 23: 59-69.

[10] Hoffman, D. and Novak, T. (1996). Marketing in Hypermedia Computer-Mediated Environments: Conceptual Foundations. Journal of Marketing 60: 50.

[11] Jun, M. and Cai, S. (2001). The key determinants of Internet banking service quality: a content analysis. International Journal of Bank Marketing 19: 276-291.

[12] Lockett, A. and Littler, D. (1997). The adoption of direct banking services. Journal of Marketing Management 13: 791811.

[13] Sohail, M. and Shanmugham, B. (2002). E-Banking and Customer Preferences in Malaysia: An Empirical Investigation. SSRN Electronic Journal 150.

[14] Mukherjee, A. and Nath, P. (2003). A model of trust in online relationship banking. International Journal of Bank Marketing 21: 5-15.

[15] Aladwani, A. (2001). Online banking: a field study of drivers, development challenges, and expectations. International Journal of Information Management 21: 213-225.

[16] Black, N. J., Lockett, A., Winklhofer, H. and Ennew, C. (2001). The adoption of Internet financial services a qualitative study. International Journal of Retail \& Distribution Management 29: 390-8.

[17] Hutchinson, D. and Warren, M. (2003). Security for Internet banking: a framework. Logistics Information Management 16: 64-73.

[18] Fedrizzi M, Molinari A, Ventre V (2004). A Model for Evaluation the Transaction Risk in E-Banking. IADIS International Conference E-Society. University of Sannio at Benevento, Italy.

[19] Sokolov, D, (2007). E-Banking: Risk Management Practices of the Estonian Banks. Institute of Economics at Tallinn University of Technology 21-37.

[20] Jaruwachirathanakul, B. and Fink, D. (2005). Internet banking adoption strategies for a developing country: the case of Thailand. Internet Research 15: 295-311.

[21] Yee - Loong Chong, A. and Ooi, K. (2008). Adoption of interorganizational system standards in supply chains.
Industrial Management \& Data Systems 108: 529-547.

[22] Bums, R. B. (1997). Introduction to Research Methods. Addison Wesley Longman Australia, South Melbourne.

[23] Akinci, S., Aksoy, Ş. and Atilgan, E. (2004). Adoption of Internet banking among sophisticated consumer segments in an advanced developing country. International Journal of Bank Marketing 22: 212-232.

[24] Byers, R. and Lederer, P. J. (2001). Retail bank services strategy: a model of traditional, electronic and mixed distribution choices. Journal of Management Information Systems 18: 133-56.

[25] Tradingeconomics.com. Vietnam GDP Growth Rate | 2000$2017 \mid$ Data $\mid$ Chart $\mid$ Calendar $\mid$ Forecast. Retrieved March 15, 2017 from http:/www.tradingeconomics.com/vietnam/gdp-growth

[26] Wilson, E. J. (2000), Closing the Digital Divide: An Initial Review: Briefing the President, May, The internet Policy Institute, Washington, D.

[27] Mattila, M., Karjaluoto, H. and Pento, T. (2003). Internet banking adoption among mature customers: early majority or laggards? Journal of Services Marketing 17: 514-28.

[28] Wilhelm, A. (2000), Democracy in the Digital Age, Routledge, New York, NY.

[29] Lee, S. J., Goles, T., Rao, S. V. and Warren, J. (2009). Trust violations in electronic commerce: customer concerns and reactions. Journal of Computer Information Systems 49: 1-9.

[30] Pikkarainen, T., Pikkarainen, K., Karjaluoto, H. and Pahnila, S. (2004). Consumer acceptance of online banking: an extension of the technology acceptance model. Internet Research 14: 224-235.

[31] Gounaris, S. and Koritos, C. (2008). Investigating the drivers of internet banking adoption decision: a comparison of three alternative frameworks. International Journal of Bank Marketing 26: 282-304.

[32] Harrison, A. and Rainer, R. (1992). The Influence of Individual Differences on Skill in End-User Computing. Journal of Management Information Systems 9: 93-111.

[33] Xuan, T. (2016). The controversially mysterious loss of money in a bank account. Retrieved February 8, 2017 from http://www.vnexpress.net

[34] McMahon, L. (1996). Dominance and survival in retail financial services: use of electronic delivery channels to optimize distribution strategy. Journal of Financial Services Marketing 21: 35-47.

[35] Friedman, B., Kahn, P. H. Jr and Howe, D. C. (2000). Trust online. Communications of the ACM 43: 34-40.

[36] Kondabagil, J. (2007). Risk management in electronic banking. 1st ed. Singapore: John Wiley \& Sons Asia.

[37] Sathye, M. (1999). Adoption of Internet banking by Australian consumers: an empirical investigation. International Journal of Bank Marketing 17: 324-334. 